\title{
Severe acute respiratory syndrome coronavirus 2 (SARS-CoV-2) exhibits high predicted binding affinity to ACE2 from lagomorphs.
}

\author{
Silvia Preziuso ${ }^{1}$ \\ ${ }^{1}$ University of Camerino School of Bioscience and Veterinary Medicine
}

April 28, 2020

\begin{abstract}
Severe acute respiratory syndrome coronavirus 2 (SARS-CoV-2) is causing the pandemic Coronavirus Disease 2019 (COVID19). The crystal structure of SARS-CoV-2 in complex with its receptor human ACE2 (hACE2) has been recently solved and the main amino acid residues involved in the complex virus-receptor have been detected. To predict whether lagomorphs can be infected by SARS-CoV-2, ACE2 sequences from rabbits, American pikas and from other mammals were compared with hACE2 sequences. Models of the complex formed by SARS-CoV-2 and ACE2 from lagomorphs and from other mammals were created for comparative studies. A low number of substitutions was found in lagomorph ACE2 sequences. Analysis of the contacts involved in the simulated complex SARS-CoV-2-ACE2 suggested that lagomorphs can be susceptible to SARS-CoV-2 infection, probably similarly to cats but lower than hamsters. These findings justify the planning of future in vitro and in vivo studies and suggest that more investigation should assess the epidemiological role of lagomorphs in SARS-CoV-2 spread. Furthermore, the risks to humans coming into close contacts with these animals should evaluated.
\end{abstract}

\section{Hosted file}

Preziuso CoV2 lagomorphs_1.doc available at https://authorea.com/users/313861/articles/444265severe-acute-respiratory-syndrome-coronavirus-2-sars-cov-2-exhibits-high-predicted-bindingaffinity-to-ace2-from-lagomorphs

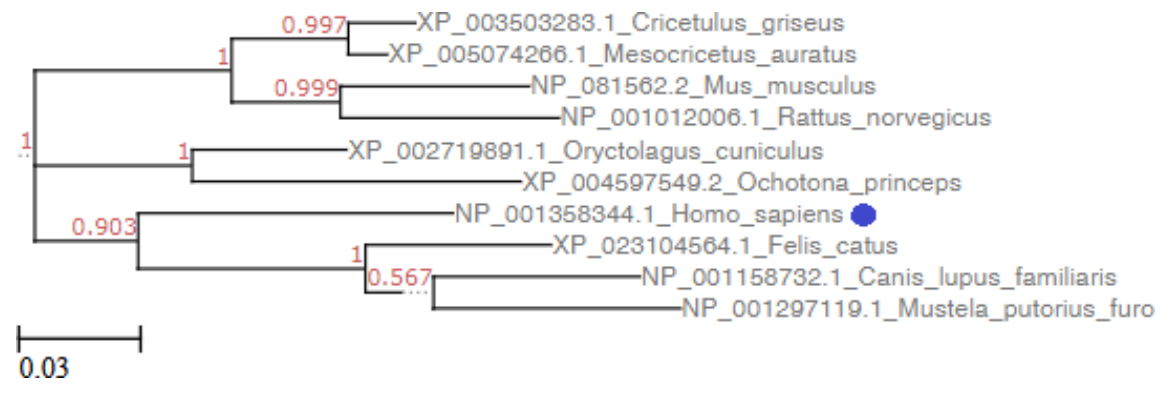




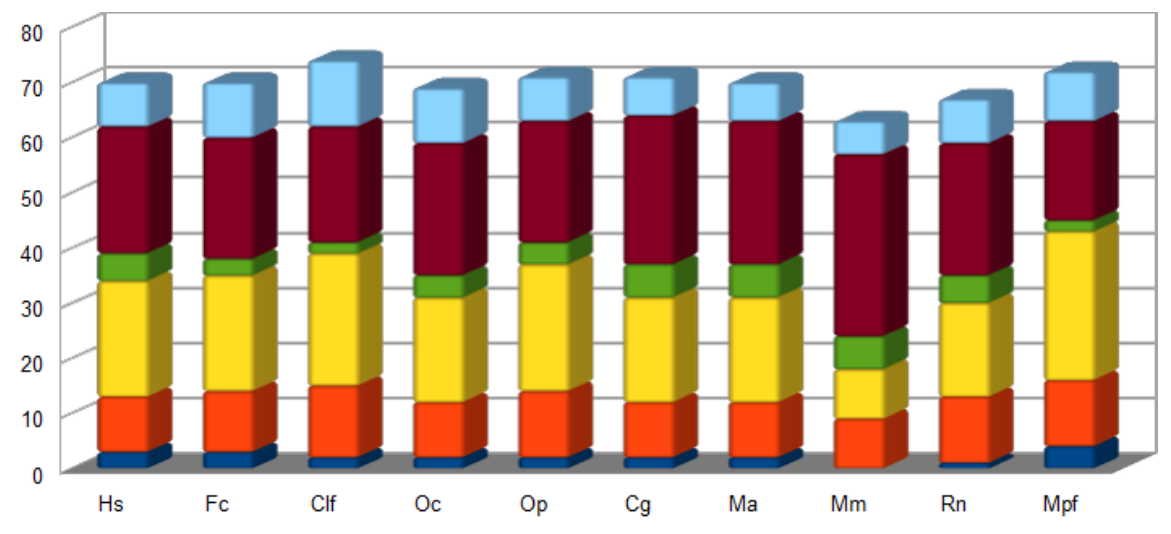

\#ICs charged-charged $\equiv$ ICs charged-polar $=I C s$ charged-apolar n ICs polar-polar $\quad$ ICs polar-apolar in ICs apolar-apolar

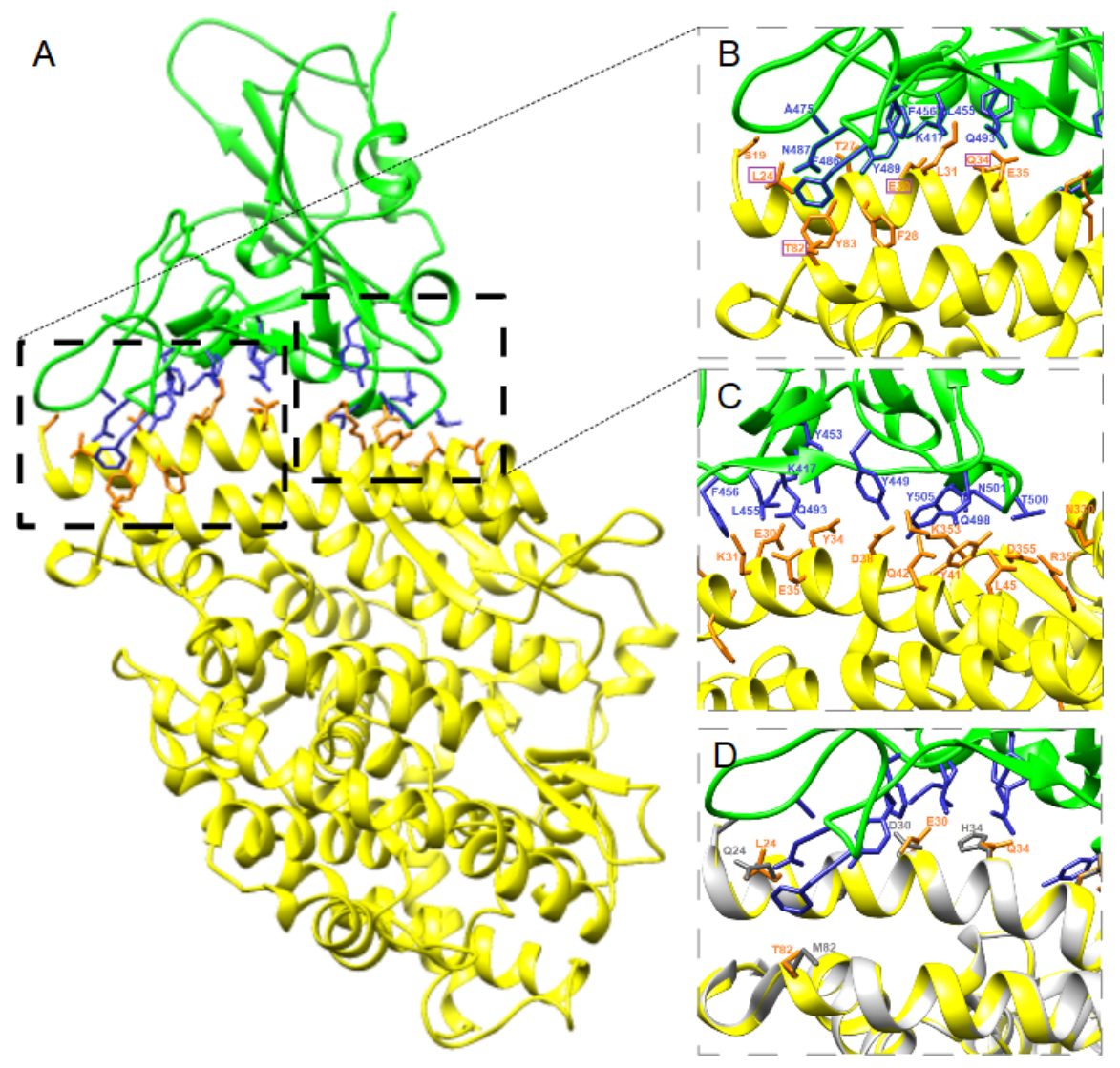




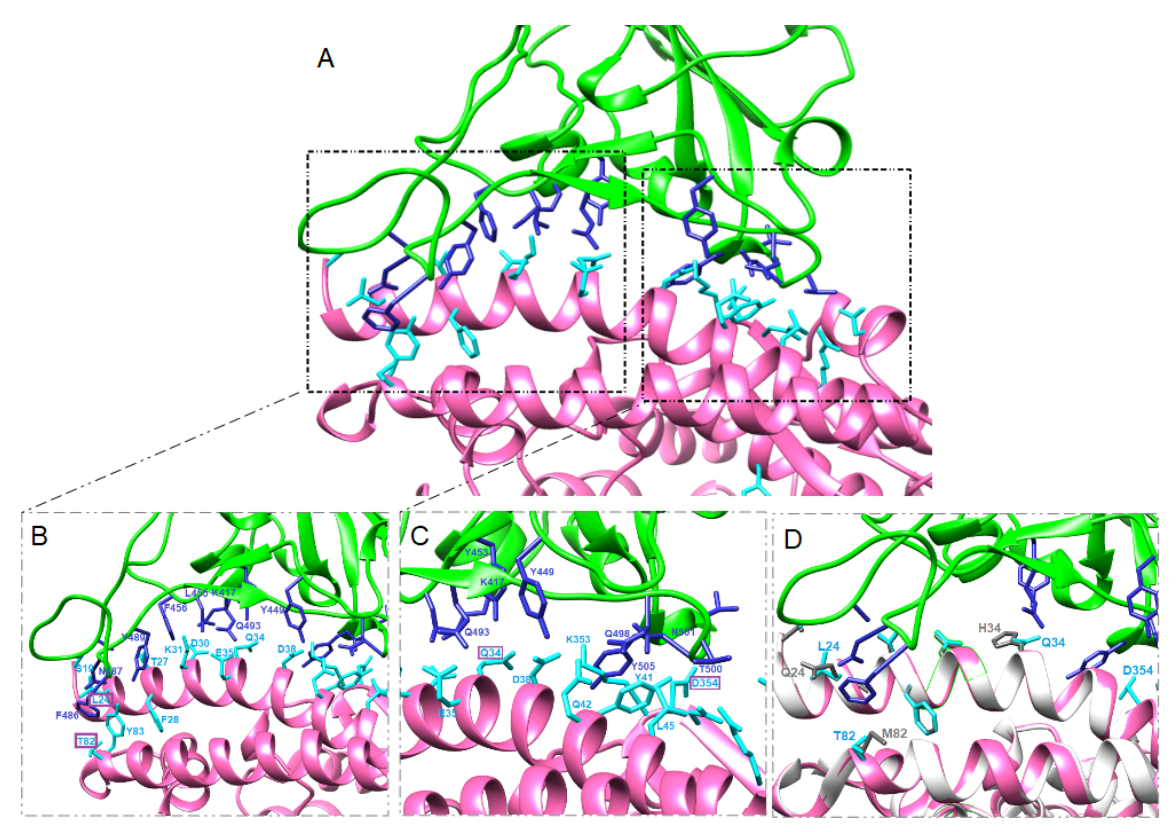

\section{Hosted file}

Tab1. doc available at https://authorea.com/users/313861/articles/444265-severe-acute-respiratorysyndrome-coronavirus-2-sars-cov-2-exhibits-high-predicted-binding-affinity-to-ace2-from-lagomorphs

\section{Hosted file}

Tab2. doc available at https://authorea.com/users/313861/articles/444265-severe-acute-respiratorysyndrome-coronavirus-2-sars-cov-2-exhibits-high-predicted-binding-affinity-to-ace2-from-lagomorphs

\section{Hosted file}

Tab3. doc available at https: //authorea.com/users/313861/articles/444265-severe-acute-respiratorysyndrome-coronavirus-2-sars-cov-2-exhibits-high-predicted-binding-affinity-to-ace2-from-lagomorphs

\section{Hosted file}

Tab4 .doc available at https://authorea.com/users/313861/articles/444265-severe-acute-respiratorysyndrome-coronavirus-2-sars-cov-2-exhibits-high-predicted-binding-affinity-to-ace2-from-lagomorphs 